\title{
Effect of germinated and heated soybean meals on plasma cholesterol and triglycerides in rats*
}

\author{
V Chandrasiri, HM Bau **, C Villaume, F Giannangeli, L Méjean
}

INSERM U 308, 38 rue Lionnois, F-54000 Nancy, France

(Received 29 December 1989; accepted 18 July 1990)

\begin{abstract}
Summary - Soybean may be useful in diets for the prevention of cardiovascular disease and the treatment of type II hyperlipoproteinemia as it lowers blood cholesterol levels. However, unpleasant organoleptic qualities and the presence of antinutritional substances hinder its use. Some of these problems may be partially solved by germinating the seeds or heating the meals. The effects of the duration of soybean germination and of heating the meal were studied in Wistar rats. Dietary meal composition, plasma cholesterol and triglyceride levels were evaluated after feeding rats with various soybean meal or casein diets containing $10 \%$ protein for 6 weeks. Plasma cholesterol and triglyceride levels were $0.81 \pm 0.11$ and $0.82 \pm 0.23 \mathrm{~g} / \mathrm{l}$ respectively after the casein diet and $0.90 \pm 0.10$ and $0.51 \pm 0.17 \mathrm{~g} / \mathrm{l}$ after the raw soybean diet. Soybean germination had a hypercholesterolemic effect $(1.05 \pm 0.11 \mathrm{~g} / \mathrm{l}$ after $5 \mathrm{~d}$ ). Heating the raw meal or germinated soybean meal did not affect cholesterol levels, though it suppressed the hypotriglyceridemic effect. The triglyceride-lowering effect of soybean was probably caused by the presence of thermolabile substances or by the quantity of food ingested. The unexpected increase in blood cholesterol levels may have been due to the effect of the low dietary protein levels.
\end{abstract}

soybean / casein / cholesterol / triglycerides / germination / heating

Résumé - Effect de farines de soja germé et chautfé sur le cholestérol et les triglycérides plasmatiques chez le rat. Le soja est un aliment qui peut s'avérer intéressant dans la prévention des maladies cardiovasculaires et pendant le traitement des hyperlipoprotéinémies de type II, puisqu'un effet hypocholestérolémiant lui est habituellement attribué. Cependant, son utilisation se heurte à des difficultés dues à sa flaveur et à l'existence de substances antinutritionnelles. La germination des graines ou le chauffage des farines élimine partiellement ces problèmes. Les influences de la durée de germination des graines de soja et du chauffage des farines obtenues ont été étudiées sur le rat Wistar. La composition des farines, la cholestérolémie et la triglycéridémie ont été évaluées après 6 semaines de consommation de diverses farines de soja ou de caséine incluses dans des régimes comportant $10 \%$ de protéines. La cholestérolémie et la triglycéridémie après ingestion du régime à base de caséine étaient respectivement de 0,81 $\pm 0,11$ et 0,82 $\pm 0,23$ g/l. Après remplacement de la caséine par de la farine de soja cru, elles devenaient $0,90 \pm 0,10$ et $0,51 \pm 0,17$ g/. La germination du soja a induit un effet hypercholestérolémiant $(1,05 \pm 0,11 \mathrm{~g} / \mathrm{l}$ après 5 jours). Le chauffage des farines de soja cru ou germé a été sans effet sur la cholestérolémie, alors que l'effet hypotriglycéridémiant était supprimé. II semblerait que l'effet hypotriglycéridémiant obtenu avec le soja soit dû à des substances thermolabiles, ou à la quantité d'aliment ingérée. L'effet hypercholestérolémiant, plus inattendu, pourraît être en liaison avec le faible taux de protéines de l'alimentation.

soja / caséine / cholestérol / triglycérides / germination / chauffage

\footnotetext{
* This study was presented in part in abstract form at the 7th Colloque International de Biologie Prospective, Pont-à-Mousson, France

** Correspondence and reprints.
} 


\section{INTRODUCTION}

Because of its composition, soybean may play a useful role in diets proposed for the prevention or treatment of cardiovascular diseases. Several studies have evaluated the effect of soybean protein on blood cholesterol levels in man and in animals (Verrillo et al, 1985; Forsythe et al, 1986; Mercer et al, 1987). The experimental conditions, however, were variable and no generally accepted explanation has yet been given for this effect. Certain authors have suggested that it was due to the lysine/arginine ratio (Kritchevsky et al, 1982), or the presence of other amino acids (Katan et al, 1982), while others have proposed that the fiber (Sharma, 1987) or saponin (Oakenfull et al, 1984) contents, the presence of lecithin (Jenkins et al, 1983), the polyunsaturated/ mono-unsaturated fatty acid ratio (Dunn and Liebman, 1986), or the level of phytosterols (Pollak and Kritchevsky, 1981) or trace elements (Samman and Roberts, 1984) were involved.

Increasing the dietary intake of soybean gives rise to certain problems due to its unpleasant organoleptic qualities and the presence of antinutritional substances (Bau, 1987).

Some of these problems may be solved by germination or heating processes, which improve the taste, odor and nutritional qualities of seeds (Chen et al, 1975; Bau and Debry, 1979; Hofsten, 1979).

We therefore studied the effects of the duration of germination and heating on soybean protein, lipid, trace element, dietary fiber and phytosterol composition, and on the plasma triglycerides and cholesterol levels of rats fed for 6 weeks with diets differing only by the nature of the protein source.

\section{MATERIALS AND METHODS}

\section{Protocol}

Twenty-one-day-old male Wistar rats weighing $50-55 \mathrm{~g}$ at the start of the study were placed in individual metabolism cages and fed the diets described below ad libitum for $42 \mathrm{~d}$. The diets were identical in composition, except for the nature of the protein source (Osborne et al, 1919). Each diet was tested on a group of 10 rats and was composed of raw whole soybean (Kingsoy, ONIDOL, Toulouse, France) meal (WM), heated soybean meal (HWM), meal prepared with 1, 3 or 5-day germinated seeds (GM1, GM3, GM5) or heated GM5 meal (HGM5). Each diet had a total protein content of $10 \%$ as this study formed part of a larger investigation on the protein efficiency ratio. For each diet, the quantity of meal necessary to supply $10 \%$ of proteins was weighed. The lipid content of each diet was adjusted to $9 \%$ with pure commercial soybean oil (Lesieur) taking into account the percentage of lipids in the meals. Five percent cellulose, $5 \%$ salt mixture and $2 \%$ vitamins (UAR, Villemoisson sur Orge) were then added, and the diets were made up to $100 \%$ with corn starch (UAR, Villemoisson sur Orge). Body weight gain, detailed meal composition and the seed germination procedure have been described elsewhere (Chandrasiri et al, 1987). The effect of soybean protein was compared with that of casein.

At the end of the study, fasting rats were anesthetized with ether under a glass bell and decapitated. Blood was collected on a mixture of EDTA and INIPROL, a protease inhibitor (Choay Laboratories, Paris). It was then centrifuged at $4^{\circ} \mathrm{C}$ and the plasma stored in aliquot fractions at $-20^{\circ} \mathrm{C}$ until assayed.

\section{Assays}

\section{In the diets}

Phytosterols were extracted from sample of the soybean meals used to prepared the test diets and assayed according to the method described by Smith et al (1987). Trace elements were analyzed using the method of Clegg et al (1981) 
with slight modifications: ashing was performed with a nitric-perchloric acid (4/1) mixture instead of nitric acid alone, and an atomic absorption spectrophotometer (Perkin-Elmer, model 400) was used. The nitrogen and lipid contents were determined according to the AOAC (1980); ethanol-soluble carbohydrates were extracted with $80 \%$ alcohol and assayed using the anthrone method (Roe, 1955). Fibers were measured according to Southgate (1969).

\section{In plasma}

Plasma cholesterol and triglyceride levels were determined enzymatically using commercial kits (Boehringer Mannheim).

\section{Data analysis}

The meal composition data (tables I, II and III) were means of triplicates with coefficients of variation of less than $5 \%$. Results were compared by a one-way ANOVA test and Fisher's test using a Macintosh computer and the Statview program. Values of $P<0.05$ were considered to be significant.

\section{RESULTS}

Body weight gain and the proximate compositions of the meals used to prepare the

Table I. la) Dietary meal compositiona (in \%).

\begin{tabular}{lcccccc}
\hline Sample & Proteins & Lipids & $\begin{array}{c}\text { Ethanol soluble } \\
\text { carbohydrates }\end{array}$ & Hemicellulose & Cellulose & Lignin \\
\hline WM & 41.6 & 20 & 14.1 & 15.8 & 3.6 & 1.3 \\
HWM & - & - & - & - & - & - \\
GM1 & 42.0 & 20.2 & 11.1 & 15.4 & 3.4 & 0.6 \\
GM3 & 44.2 & 17.2 & 8.2 & 14.5 & 2.4 & traces \\
GM5 & 46.6 & 16.2 & 2.8 & 13.3 & 0.4 & traces \\
HGM5 & - & - & - & - & - & - \\
Casein & 83.1 & - & - & - & - & -
\end{tabular}

lb) Body weight gain and protein intake (in g).

\begin{tabular}{lcc}
\hline Sample & Daily body weight gain & Daily protein intake \\
& & \\
\hline WM & $1.4 \pm 0.3$ & $1.1 \pm 0.1$ \\
HWM & $3.7 \pm 0.3$ & $1.6 \pm 0.1$ \\
GM1 & $2.1 \pm 0.4$ & $1.3 \pm 0.2$ \\
GM3 & $1.3 \pm 0.4$ & $1.0 \pm 0.1$ \\
GM5 & $1.1 \pm 0.4$ & $0.9 \pm 0.1$ \\
HGM5 & $2.7 \pm 0.3$ & $1.3 \pm 0.1$ \\
Casein & $4.1 \pm 0.4$ & $1.5 \pm 0.1$ \\
\hline
\end{tabular}

a Dry weight basis; WM: raw whole soybean meal; HWM: heated soybean meal; GM1, GM3, GM5: 1, 3 or 5-day germinated soybean meal; HGM5: heated GM5. 
Table II. Trace element contentsa.

\begin{tabular}{llll}
\hline Sample & Zinc & Copper & Zn/Cu \\
\hline WM & 47.7 & 13.66 & 3.49 \\
GM1 & 54.45 & 11.74 & 4.64 \\
GM3 & 56.7 & 12.82 & 4.42 \\
GM5 & 54.9 & 12.58 & 4.36 \\
\hline
\end{tabular}

a Dry weight basis $(\mu g / g)$; WM: raw whole soybean meal; GM1, GM3, GM5: 1, 3 or 5-day germinated soybean meal.

diets are given in table I. Increasing the duration of germination led to an increase in the protein content, a decrease in the lipid, hemicellulose, cellulose and lignin contents and a large fall in the ethanolsoluble carbohydrate content of the meal.

The trace element content of the meals is shown in table II. There was an irregular change in $\mathrm{Cu}$ and $\mathrm{Zn}$ with the increasing duration of germination. The $\mathrm{Zn} / \mathrm{Cu}$ ratio increased with germination time.
Phytosterol contents are shown in table III. The phytosterol contents of sunflower seeds and rapeseed oils are also given for comparison. Germination of soybean seeds led to an increase in almost all phytosterols, and especially in $\beta$-sitosterol.

The effects of the different diets on blood cholesterol and triglyceride levels as a function of germination time and heat treatment are shown in table IV. The statistical significance of differences between pairs of diets is also given.

Variance analysis showed that the diet had a global effect on cholesterol $\left(F_{6,63}=\right.$ 12.5) and triglyceride levels $\left(F_{6.63}=4.37\right)$.

Analysis of variance attributable to germination for diets WM, GM1, GM3 and GM5 showed that germination time affected both cholesterol $\left(F_{3.36}=9.83\right)$ and triglyceride levels $\left(F_{3.36}=3.47\right)$. Compared with the casein diet, the crude soybean meal diet led to a non-significant increase in cholesterol and a significant decrease in triglycerides. The heated meal produced a very large increase in triglycerides, while cholesterol was unchanged. Similarly, the

Table III. Phytosterol contenta of soybean oils prepared after different germination durations.

\begin{tabular}{lrrrrrrr}
\hline Phytosterol & WM & GM1 & GM2 & GM3 & GM5 & $\begin{array}{c}\text { Sunflower } \\
\text { oil }\end{array}$ & $\begin{array}{c}\text { Rapeseed } \\
\text { oil }\end{array}$ \\
\hline$\gamma$-tocopherol & 9.3 & 12.4 & 12.3 & 10.5 & 12.3 & & \\
$\alpha$-tocopherol & 10.1 & 6.9 & 7.2 & 6.3 & 16.1 & & \\
$\Delta$-7avenasterol & 14.1 & 9.9 & 17.1 & 11.2 & 18.5 & & \\
Campesterol & 82.8 & 71.8 & 67.0 & 84.7 & 94.9 & 11.2 & 40.0 \\
$\beta$-sitosterol & 147.1 & 174.8 & 150.3 & 180.5 & 222.7 & 69.5 & 56.1 \\
$\Delta-7$ stigmasterol & 14.9 & 15.2 & 16.6 & 17.3 & 18.6 & 10.3 & 1.6 \\
$\Delta-5$ avenasterol & 15.1 & 12.4 & 14.8 & 16.4 & 21.6 & 4.6 & 4.1 \\
Stigmasterol & 81.4 & 67.8 & 99.6 & 100.5 & 99.9 & 8.2 & 0.6 \\
Brassicasterol & & & & & & & 10.8 \\
\hline
\end{tabular}

a $\mathrm{mg} / 100 \mathrm{~g}$ (dry weight basis); WM: raw whole soybean meal; GM1, GM2, GM3, GM5: 1, 2, 3, 5-day germinated soybean meals. 
Table IV. Effect of diet on plasma cholesterol and triglyceride levels (mean $\pm S D$ ).

\begin{tabular}{ccc}
\hline Diet & $\begin{array}{c}\text { Cholesterol } \\
(g /)\end{array}$ & $\begin{array}{c}\text { Triglycerides } \\
(g /)\end{array}$ \\
\hline
\end{tabular}

$\begin{array}{lll}\text { WM } & 0.90 \pm 0.10^{\mathrm{a}, \Theta} & 0.51 \pm 0.17^{\mathrm{a}} \\ \text { HWM } & 0.83 \pm 0.14^{\mathrm{a}} & 0.85 \pm 0.26^{\mathrm{b}, e} \\ \text { GM1 } & 0.98 \pm 0.19^{\mathrm{b}, \mathrm{e}} & 0.830 .40^{\mathrm{b}, \mathrm{f}} \\ \text { GM3 } & 1.26 \pm 0.19^{\mathrm{c}} & 0.64 \pm 0.41^{\mathrm{a}, \mathrm{b}, \mathrm{c}} \\ \text { GM5 } & 1.05 \pm 0.11^{\mathrm{b}, \mathrm{d}} & 0.42 \pm 0.07^{\mathrm{a}, \mathrm{c}} \\ \text { HGM5 } & 1.14 \pm 0.17^{\mathrm{c}, \mathrm{d}} & 0.96 \pm 0.39^{\mathrm{d}, e, f} \\ \text { Casein } & 0.81 \pm 0.11^{\mathrm{a}} & 0.82 \pm 0.23^{\mathrm{b}, \mathrm{d}}\end{array}$

Means not sharing the same superscript letter in the same column are significantly different at $P<0.05$. WM: raw whole soybean meal; HWM: heated soybean meal; GM1, GM3, GM5: 1, 3 or 5-day germinated soybean meals; HGM5: heated GM5.

heated germinated seed meal (HGM5) induced a large increase in triglyceride levels, whereas it did not affect cholesterol.

Seed germination and duration of germination induced complex variations in triglyceride and cholesterol levels as compared to raw soybean meal or casein.

Germinated soybean seeds induced higher cholesterol levels than casein or raw meal. One-day germinated seeds induced a significant increase in triglycerides. When the germination time was extended, the triglyceride levels were significantly lower than those observed with the casein diet.

\section{DISCUSSION}

The hypocholesterolemic effect of dietary soybean protein in comparison with casein has been attributed to phytosterols, lecithin, the Lys/Arg ratio, dietary fibers, the poly/mono unsaturated fatty acid ratio or saponins (Pollak and Kritchevsky, 1981; Katan et al, 1982; Kritchevsky et al, 1982; Jenkins et al, 1983; Oakenfull et al, 1984; Samman and Roberts, 1984; Dunn and Liebman, 1986; Sharma, 1987).

Our results showed that dietary intake of germinated soybean protein led to a significant increase in plasma cholesterol, whereas no decrease was observed with raw soybean meal.

In rats, the hypocholesterolemic effect generally described with soybean diets was usually obtained with diets containine $20 \%$ protein. These results cannot therofore be compared to our results obtair $3 d$ with $10 \%$ protein diets as variations in the dietary protein content may modify the nature of the dietary effect on plasma cholesterol. Leszczynski et al (1987) has shown that plasma cholesterol and phospholipids fell in female chicks fed a $24.8 \%$ protein diet in comparison with a $12.8 \%$ protein diet. Sugiyama et al (1986) also reported that the effect on plasma cholesterol of the same methionine supplement was inversed when the dietary protein content was increased from 10 to $25 \%$.

Modifications in the micronutrient composition of the soybean meals tested may explain the metabolic effect observed after feeding with meals obtained from germinated soybean seeds.

During germination, there was an increase in the zinc levels with little change in copper so that the $\mathrm{Zn} / \mathrm{Cu}$ ratio in the diets increased with germination. As dietary mineral levels are good indicators of plasma mineral levels which influence plasma cholesterol levels (Katya-Katya ef al, 1984; Klevay, 1975), such an increase in the $\mathrm{Zn} / \mathrm{Cu}$ ratio may have been responsible for the concomitant increase in plasma cholesterol.

Phytosterols have a hypocholesterolemic effect through their action on intestinal cholesterol absorption (Pollak and Kritch- 
evsky, 1981) and/or synthesis. Soybean oil is naturally rich in campesterol, $\beta$ sitosterol and stigmasterol compared to rapeseed and sunflower seed oils. Prolonged germination leads to an increase in phytosterols, and especially $\beta$-sitosterol. This increase may promote a decrease in plasma cholesterol.

Compared with a casein diet, a soybean diet may be hypocholesterolemic due to its dietary fiber content (Sharma, 1987) so that the decrease in fiber content during germination has a hypercholesterolemic effect.

In brief, prolonged germination modifies the levels of some of the parameters affecting plasma cholesterol levels. There was an increase in the $\mathrm{Zn} / \mathrm{Cu}$ ratio (hypercholesterolemic effect), and phytosterol content (hypocholesterolemic effect) and a decrease in the fiber content (hypercholesterolemic effect).

However, as the plasma cholesterol level increased in our study using $10 \%$ protein diets, the influence of the $\mathrm{Zn} / \mathrm{Cu}$ ratio and the decreased dietary fiber content were not overcome by the increased phytosterol content. This is not really unexpected since phytosterols have no hypocholesterolemic effect in rats on a cholesterol-free diet (Sugano et al, 1977).

Our results demonstrate that dietary soybean meals have a global effect on plasma triglyceride levels. Dietary intake of a raw soybean meal led to a significant decrease in the triglyceride levels in comparison with the casein diet. Similar results have been reported (Jenkins et al, 1983) with a soybean protein concentrate in $10 \%$ protein diets in rats, and with a soybean protein isolate in $20 \%$ protein diets in rats (Sugano et al, 1982). Tsai et al (1987) also obtained such an effect with soybean fiber. Our results using germinated soybean meal cannot be satisfactorily explained by the fiber content, as the hypotriglyceridem- ic effect was suppressed after one day of germination when there was no change in fiber content. When germination was prolonged, the hypotriglyceridemic effect occurred despite the decrease in fiber content.

Different authors have demonstrated the presence of lipase inhibitors in various germs and seeds (Satouchi and Matsushita, 1976; Gargouri et al, 1984; Wang and Huang, 1984; Lairon et al, 1985; Glenn and Chapman, 1987). These authors suggested that certain proteins reacting with lipids may affect intestinal lipolysis and thus influence lipid absorption and metabolism. Such a mechanism may partially explain the results obtained here for the difference between casein and raw soybean meal as well as the effect of germination (increase in lipase inhibitor with germ development).

Heat treatment of both raw soybean meal (WM) and germinated soybean meal (GM5) led to a decrease in the hypotriglyceridemic effect with no effect on cholesterolemia. These results suggest that the factor involved in the hypotriglyceridemic effect is thermolabile.

On the other hand, hepatic secretion of triglycerides incorporated in hepatic lipoproteins reflects the dietary triglyceride intake, and rats fed with raw or germinated soybean had a lower daily food intake than rats fed with heated soybean or casein (table 1). Studies with pair-fed rats will be performed to estimate the effect of food intake on blood lipids.

\section{CONCLUSION}

Lower triglyceride levels were obtained in rats fed $10 \%$ soybean protein diets than in those fed casein. Prolonging seed germination produced variations in the main factors considered to be responsible for the 
hypocholesterolemic effect such as the $\mathrm{Zn} /$ $\mathrm{Cu}$ ratio and fiber content. Heated flours still retained their hypercholesterolemic effect, whereas the hypotriglyceridemic effect was suppressed suggesting that the hypotriglyceridemic effect obtained with soybean was due to thermolabile factors. However, it may also be related to the food intake. The hypercholesterolemic effect was apparently produced by mechanisms associated with the dietary protein content, experimental conditions (species and age of animals, duration of experiments), and composition of the meals.

\section{ACKNOWLEDGMENTS}

This study was supported by a grant from the FRMF (Fondation de la Recherche Médicale de France, section Lorraine). We thank C Habert for typing and page-setting this manuscript.

\section{REFERENCES}

AOAC (1980) Official Methods of Analysis. Assoc Official Analytical Chemists, Washington, DC, 13th edn

Bau HM, Debry G (1979) Germinated soybean protein products chemical and nutritional evaluation. J Am Oil Chem Soc 56, 160-162

Bau HM (1987) Les constituants biochimiques de quelques graines d'oléagineux et de légumineuses. Thèse de Docteur ès Sciences, Université de Nancy I, $169 p$

Chandrasiri V, Bau HM, Villaume C, Giannangeli F, Lorient D, Mejean L (1987) Effet de la germination de la graine de soja sur la composition et la valeur nutritionnelle de sa farine. Sci Alim 7 (VIII), 139-150

Chen LH, Hells CE, Fordham JR (1975) Germinated seeds for human consumption. $J$ Food Sci 40, 1290-1294

Clegg MS, Keen CL, Lonnerdal B, Hurley LS (1981) Influence of ashing techniques of the analysis of trace elements in animal tissue. I. Wet ashing. Biol Trace Elem 3, 107-115

Dunn C, Liebman M (1986) Plasma lipid alterations in vegetarian males resulting from the substition of tofu for cheese. Nutr Res 6, 1343-1352

Forsythe WA, Green MS, Anderson JJB (1986) Dietary protein effects on cholesterol and lipoprotein concentrations: a review. J Am Coll Nutr 5, 533-549

Gargouri Y, Julien R, Pieron G, Verger R, Sarda $L$ (1984) Studies on the inhibition of pancreatic and microbial lipases by soybean proteins. J Lipid Res 25, 1214-1221

Glenn W, Chapman JR (1987) A proteinaceous competitive inhibitor of lipase isolated frc I Helianthus annuus seeds. Phytochemis. $y$ 26, 3127-3131

Hofsten BV (1979) Legume sprouts as a souive of protein and other nutrients. J Am Oil Chem Soc 56, 382-388

Jenkins MY, Mitchell GV, Vanderveen JE, Adkins JS, Edwards CH (1983) Effects of dietary protein and lecithin on plasma and liver lipids and plasma lipoprotein in rats. Nutr Rep Int 28, 621-634

Katan MB, Vrooman L, Hermus RJ (1982) Reduction of casein induced hypercholesterole$\mathrm{mia}$ and atherosclerosis in rabbits and rats by dietary glycine, arginine and alanine. Atherosclerosis 43, 381-391

Katya-Katya $M$, Ensminger A, Méjean L, Debry $G$ (1984) Effect of zinc supplementation on plasma cholesterol levels. Nutr Res 4, 633638

Klevay LM (1975) Coronary heart disease: the zinc/copper hypothesis. Am J Clin Nutr 28, 764-774

Kritchevsky D, Tepper SA, Czarnecki SK, Klurfeld DM (1982) Atherogenicity of animal and vegetable protein. Influence of the lysine to arginine ratio. Atherosclerosis 41, 429-431

Lairon D, Borel P, Termine E, Grataroli R, Chabert C, Hauton JC (1985) Evidence for a proteinic inhibitor of pancreatic lipase in cereals, wheat bran and wheat gum. Nutr Rep Int 32, 1107-1113

Leszczynski DE, Mason WR, Kummerow FA (1987) Dietary fatty acid and protein effects on plasma and liver lipids. Nutr Res 7, 413420 
Mercer NJH, Carroll KK, Giovannetti PM, Steinke FH, Wolfe BM (1987) Effects on human plasma lipids of substituting soybean protein isolate for milk protein in the diet. Nutr Rep Int 35, 279-287

Oakenfull DG, Topping DL, Illman RJ, Fenwick DE (1984) Prevention of dietary hypercholesterolemia in the rat by soya bean and quillaja saponins. Nutr Rep Int 29, 1039-1046

Osborne TB, Mendel LB, Ferry EL (1919) A method of expressing numerically the growth promoting value of protein. $J$ Biol Chem 37, 223-229

Pollak OJ, Kritschevsky D (1981) Sitosterol. S Karger, Basel, pp 220

Roe JH (1955) The determination of sugar in blood and spinal fluid with anthrone reagent. J Biol Chem 212, 335-343

Samman S, Roberts DCK (1984) The phosphorylation state of casein and its hypercholesterolaemic effect: role of divalent cations. Atherosclerosis 52, 347-348

Satouchi K, Matsushita S (1976) Purification and properties of a lipase inhibiting protein from soybean cotyledons. Agric Biol Chem 40, 889-897

Sharma RD (1987) An evaluation of hypercholesterolemic activity of some uncommon legumes. Nutr Res 7, 351-363

Smith RL, Sullivan DM, Richter EF (1987) Determination of phytosterols in butter samples by using capillary column. $J$ Assoc Off Anal Chem 70, 912-915

Southgate DAT (1969) Determination of carbohydrates in food. II. Unavailable carbohydrates. J Sci Food Agric 20, 331-335

Sugano M, Morioka H, Ikeda I (1977) A comparison of hypercholesterolemic activity of $\beta$ sitosterol and $\beta$-sitostanol in rats. J Nutr 107, 2011-2019

Sugano MS, Ishiwaki N, Nagata $Y$, Imaizumi K (1982) Effects of arginine and lysine addition to casein and soya bean protein on serum lipids, apolipoproteins, insulin and glucagon in rats. Br J Nutr 48, 211-221

Sugiyama K, Akai $H$, Muramatsu K (1986) Effects of methionine and related compounds on plasma cholesterol level in rats fed a high cholesterol diet. J Nutr Sci Vitaminol 32, 537 549

Tsai AC, Vinik Al, Lasichak A, Lo GS (1987) Effects of soy polysaccharide on postprandial plasma glucose, insulin, glucagon, pancreatic polypeptide, somatostatin, and triglyceride in obese diabetic patients. Am J Clin Nutr 45, 596-601

Verrillo A, De Teresa A, Giarrusso PC, La Rocca $S$ (1985) Soybean protein diets in the management of type If hyperlipoproteinaemia. Atherosclerosis 54, 321-331

Wang $S$, Huang $A C H$ (1984) Inhibitors lipase activities in soybean and other oil seeds. Plant Physiol 76, 929-934 